\title{
Characterization of the communication resources used by patients in palliative care - an integrative review
}

Carmen Lucianna Miranda e Silva(1) Camila Bertoncelo(1)

Ana Paula Brandão Barros ${ }^{(1)}$

Marina Padovani ${ }^{(1)}$

(1) Escola Superior da Amazônia Esamaz, Belém, Pará, Brazil.

Conflict of interest: Nonexistent

Received on: July 19, 2017

Accepted on: September 19, 2017

Mailing address:

Carmen Lucianna Miranda e Silva

Rua Piata, 323, Vila Isolina Mazzei

CEP: 02080-010 - São Paulo, São Paulo, Brasil

E-mail: carmenlucianna@alumni.usp.br

\section{ABSTRACT}

The aim of this study was to integrative review of publications concerning the role of speech and language therapists in regards to communication strategies in palliative care, as well as the characterization of the types of communication used in these cases. The search was conducted in the databases SciELO, LILACS and PubMed from 2001 to 2016. The studies selected included abstracts or full articles addressing aspects of communication in palliative care, especially those related to speech and language therapy, with an emphasis on communication. Ten articles focused on communication, and published after 2004, were selected, half being literature reviews, two, case reports, two others, quantitative exploratory studies, and one, a qualitative exploratory study, with only 3 specifically describing the communication strategies used by speech and language therapists in patients in palliative care. The descriptors found were: palliative care, communication, speech and language therapy, quality of life, dysphagia, swallowing and elderly. Four of the ten articles showed the importance of patients communication in palliative care. When described, it is up to the speech and language therapist to provide family support, evaluate the patient, favore patient-family and patient-team intervention, manage and intervene in communication and swallowing. Finally, the most used communication strategies were non-verbal communication, communication board, electronic equipment, verbal communication and speech valve. The analysis of the characterization of the communication in palliative care over the past 15 years allowed concluding that the attention to communication is recent and is only described in a few reports, includes non-verbal communication in different ways as the most frequent resource, but provides oral communication as an important factor for maintaining dignity and comfort in this scenario. Speech and language therapist are the main interlocutors for the maintenance, mediation and adaptation of communication, within the multidisciplinary team as well as among patients, their family and the care team.

Keywords: Palliative Care; Hospice Care; Communication; Communication Methods, Total; Communication Disorders 


\section{INTRODUCTION}

The World Health Organization $(\mathrm{WHO})^{1}$ defines palliative care as an approach that promotes the quality of life of patients and family members in the face of life-threatening diseases through the prevention and relief of suffering. It includes the early identification, evaluation and impeccable treatment of pain and other physical, psychosocial and spiritual problems.

Palliative care should be the responsibility of a multidisciplinary team that will combine its knowledge and acts to improve the quality of life of these patients ${ }^{2,3}$.

Speech therapy has an important role within the team, acting mainly in the areas of communication, voice and swallowing. It is the role of the speech and language therapist to try to maintain functional swallowing, to bring comfort and oral pleasure to the patient and to adapt communication alternatives that seek effective interaction between patient and family and patient and team, keeping the patient capable of expressing his decisions and ensuring his social contact ${ }^{4}$.

Patients in palliative care with neurological diseases, such as stroke, neuromuscular diseases with a progressive degenerative course, brain tumors, and laryngeal tumors among other head and neck tumors, may present significant impairments in communication and voice as a consequence of the pathology. Communication is of utmost importance for the treatment and well-being of these patients, enabling a better quality of life and reducing the emotional pain of all those involved ${ }^{2,4-6}$.

The role of the speech and language therapist in palliative care is unfortunately still poorly understood, even among speech and language therapists themselves and also by other health professionals ${ }^{4,7}$.

The literature reports that when alternative communication strategies are used, they are generally well accepted by patients and families, as they allow them to participate in their treatment decisions and also express their latest messages. These strategies range from simple and inexpensive materials such as communication boards, drawings and writing, to expensive electronic equipment ${ }^{8}$.

Understanding the possibilities of the speech and language therapist in the communication of subjects in palliative care, as well as the strategies used for this, was the reason for this study.

The objective of this work was to carry out an integrative review of the publications regarding the role of the speech and language therapist in regards to communication strategies in palliative care, as well as the characterization of the types of communication used in these cases.

\section{METHODS}

This integrative review study was carried out with the collection of periodical articles from the following databases: PubMed, SciELO and LILACS, in the period between May and July 2016. The search included original research articles and bibliographic reviews published from 2001 to July 2016 in Portuguese, English and Spanish and which were fully available online. The search retrieved 383 articles in the SciELO database, 47,286 in the PubMed database and 1,224 in the LILACS database, which were initially retrieved from a search using the keyword palliative care. Then, the keywords communication and speech and language therapy were added, separately. Of these, the selection included those dealing with aspects of communication in palliative care, especially those related to speech and language therapy intervention, with an emphasis on communication. These data were identified in the abstract and after a complete reading of the articles, they were included in the sample, yielding a total of 11 articles identified in the flowchart in the cell "palliative care and speech and language therapy", in each database, with 1 of them being repeated in the LILACS database, thus yielding 10 articles for the analysis (Figure 1). 


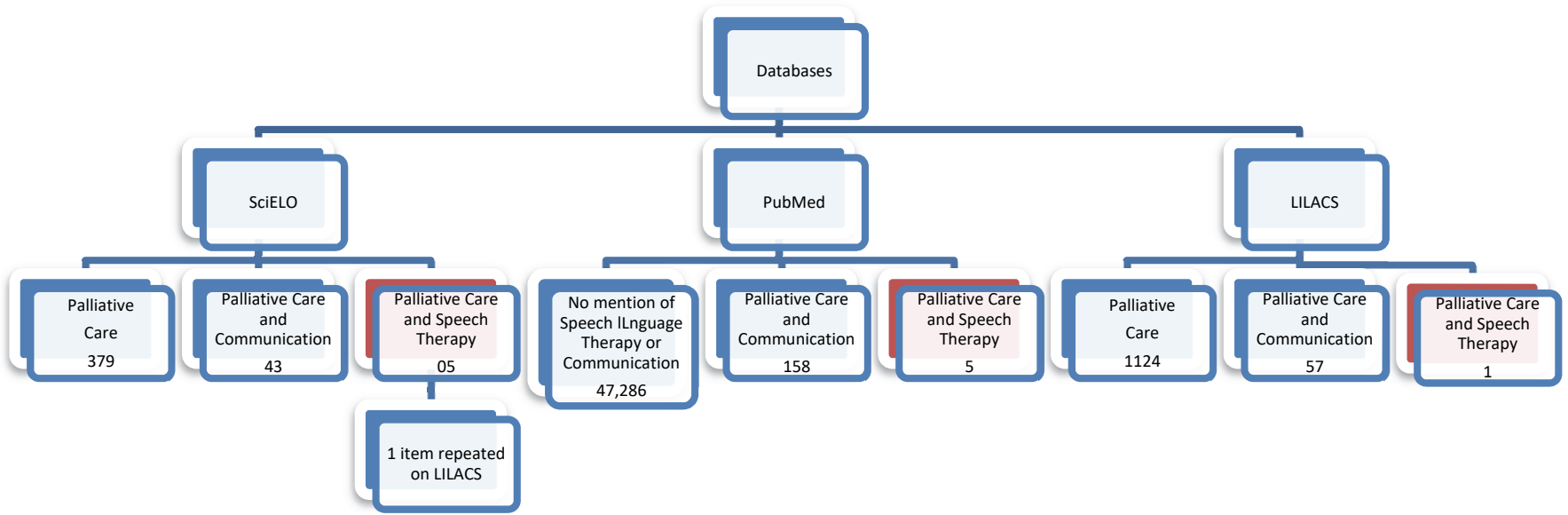

Figure 1. Flowchart of the data search

The keywords used for the survey were: "Speech and Language Therapy in Palliative Care," "Communication and Palliative Care" and "Palliative Care."

The selected articles were read and then analyzed for the following aspects: year of publication, type of study, descriptors, role and/or participation of the speech and language therapist, means and aspects of communication. Such data were identified in the abstract or in the integral reading of the article to be included in the sample.

The present integrative review study contemplates an approach focused on clinical care and is based on the knowledge and the purpose of the evidence, where it is possible to analyze experimental and non-experimental studies, search for similarities and differences among the articles and to insert, in this analysis, experiences by the authors, which results in a synthesis of practical application with respect to the patient ${ }^{9}$.

\section{LITERATURE REVIEW}

It was possible to identify the insertion of the communication in the scientific discussion in palliative care only from 2004 onwards, with 10 articles selected (Annex 1), with a maximum of 2 articles per year, and in 8 years no publications were found with the subject investigated (Figure 2).

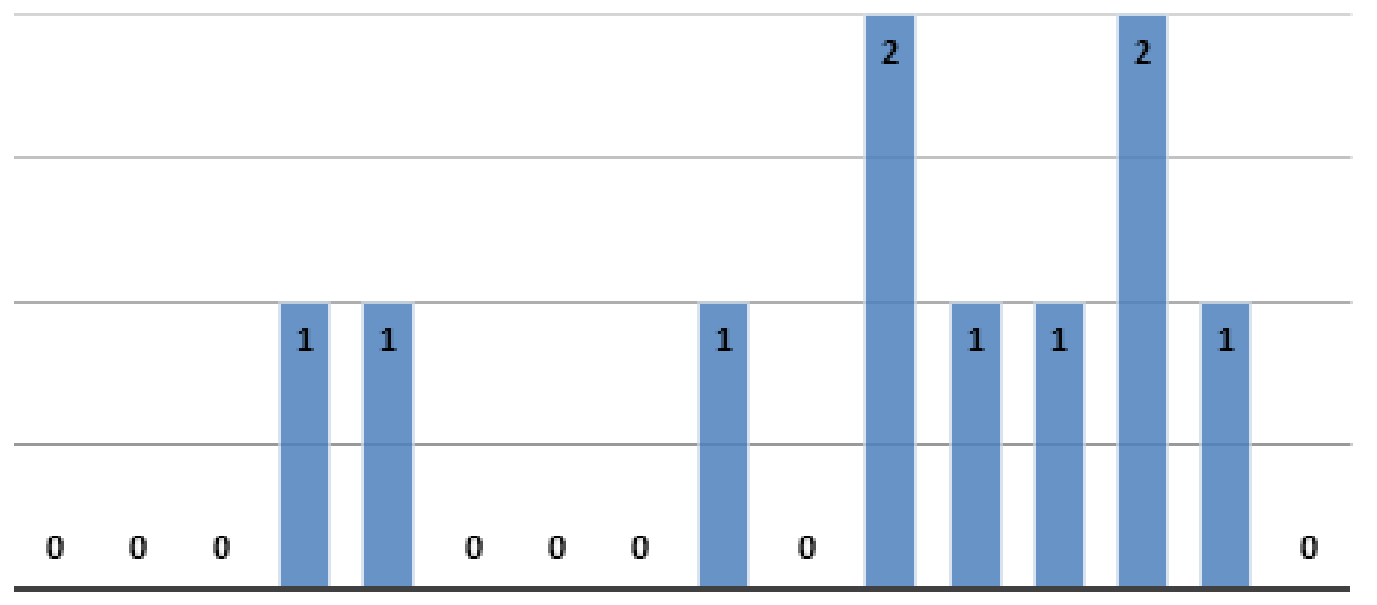

2001200220032004200520062007200820092010201120122013201420152016

Figure 2. Distribution of the number of articles per year 
Of the articles found, half of them were bibliographical reviews $(5,50 \%)$, two $(2,20 \%)$ were case reports, another two $(2,20 \%)$ were quantitative exploration studies and one $(1,10 \%)$ was a qualitative

exploration study (Figure 3).

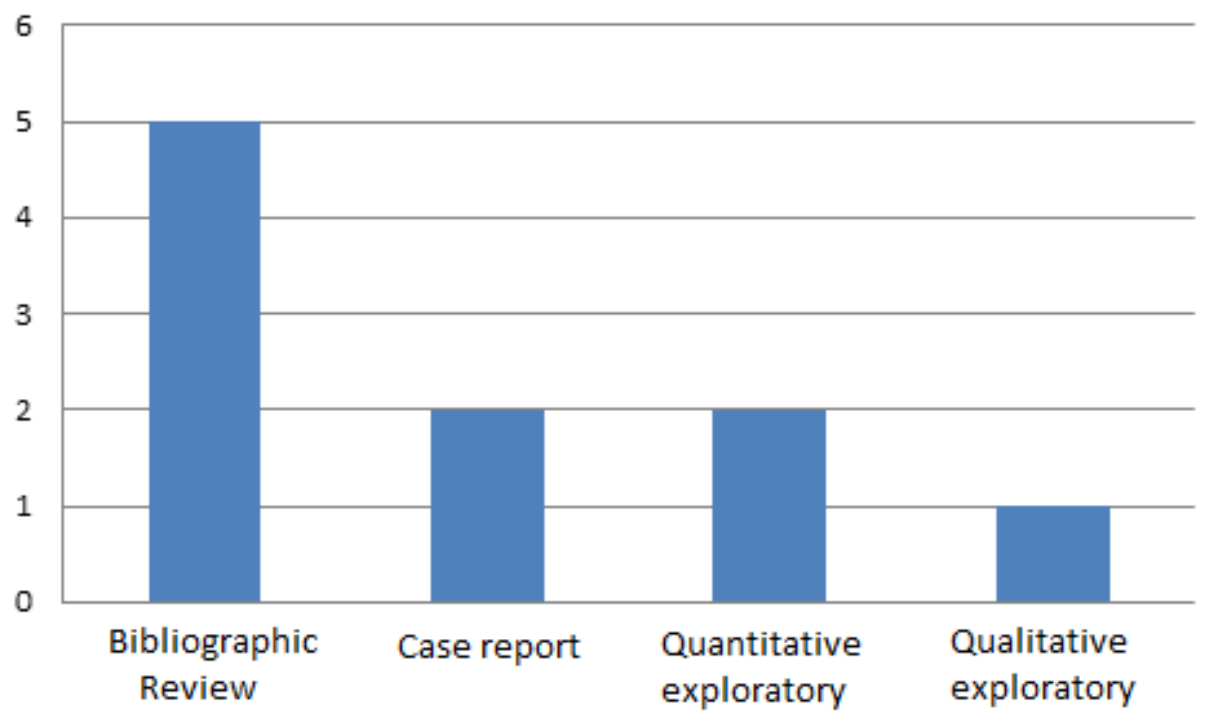

Figure 3. Distribution of types of studies

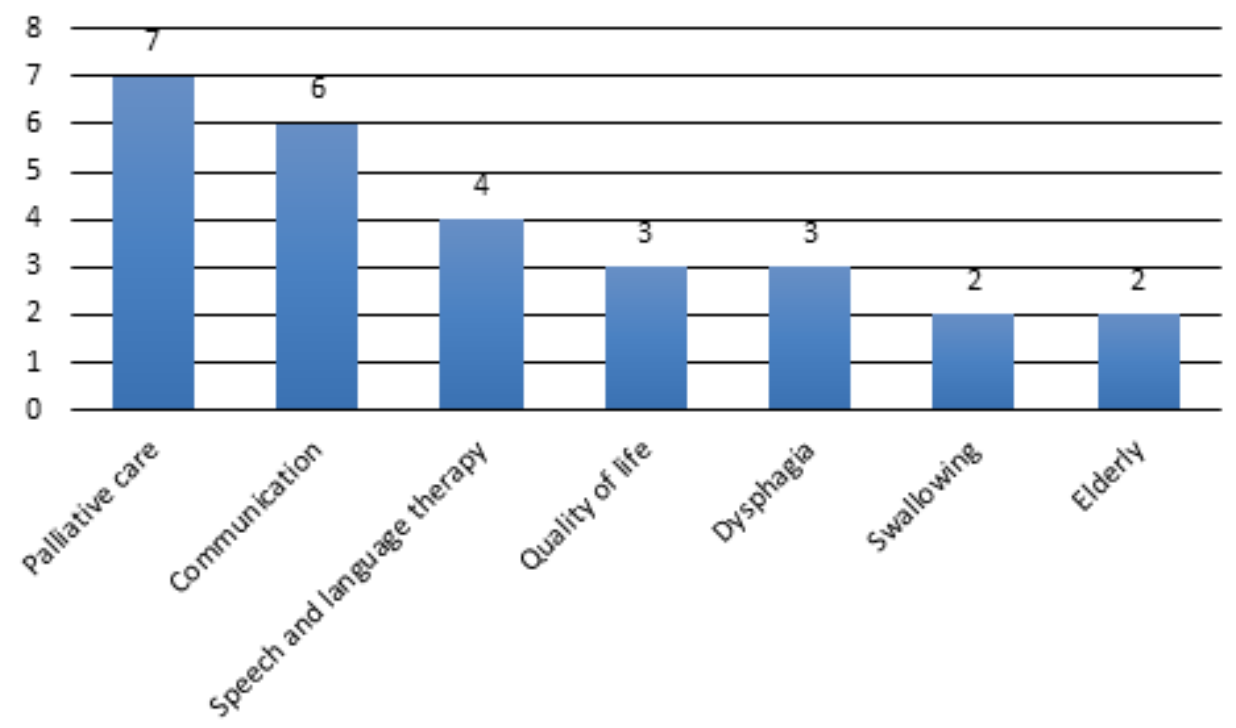

Figure 4. Frequency of the descriptors found in the databases 
The descriptors found were (Figure 4): palliative care, communication, speech and language therapy, quality of life, dysphagia, swallowing and elderly.

The participation of the speech and language therapist in palliative care (Figure 5) was not mentioned in $40 \%$ of the articles and, when described, occurred in a diversified way, including: favoring patient-family and patient-team intervention (45\%), managing and intervening in communication and swallowing (35\%), offering family support (11\%) and evaluating the patient (11\%).

As for the communication means and/or aspects used for the communication intervention, 5 (50\%) articles presented suggestions for communication

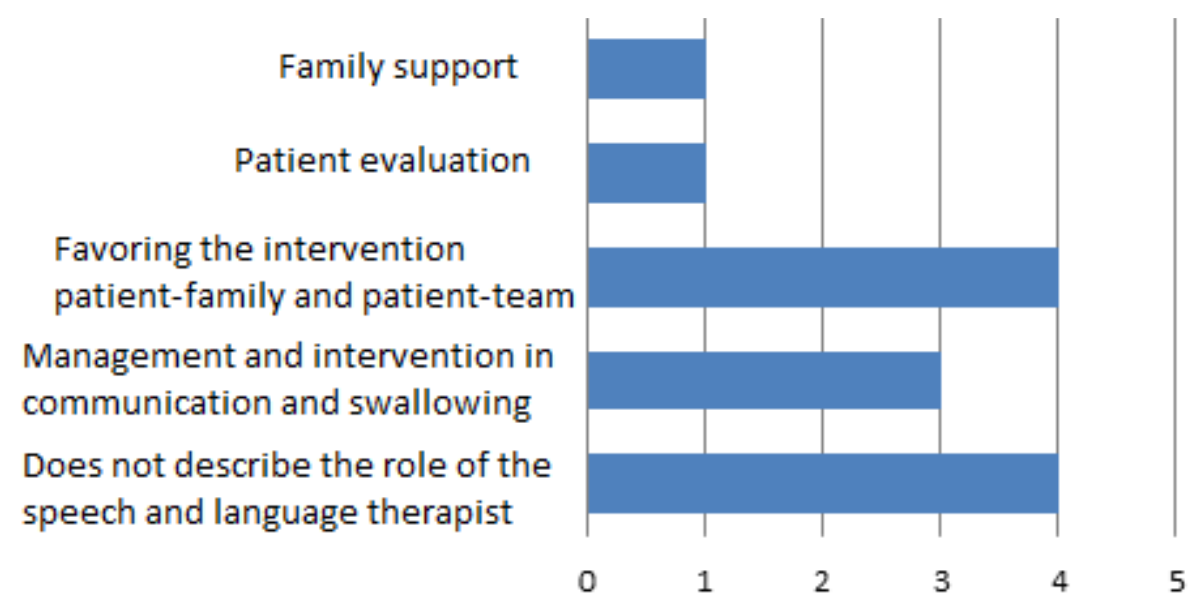

Figure 5. Distribution of the role/participation of the speech and language therapist in palliative care

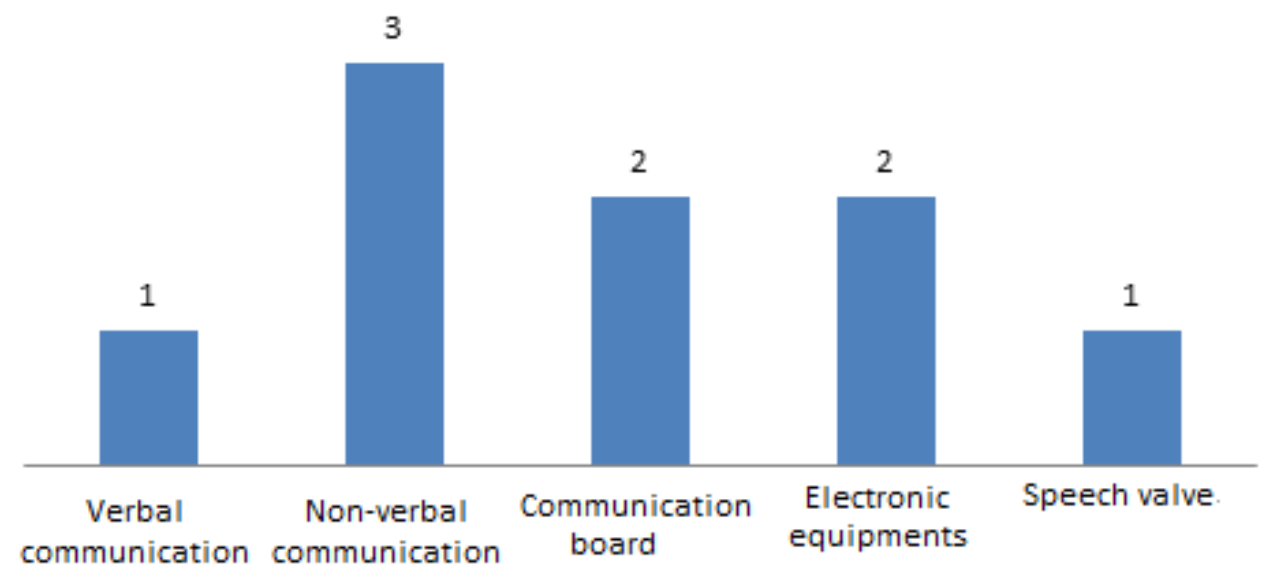

Figure 6. Graph of the communication strategy used by patients in palliative care

strategies (Figure 6); these were: non-verbal communication (33.4\%), communication board (22.2\%), electronic equipment $(22.2 \%)$, verbal communication $(11.1 \%)$ and speech valve (11.1\%).

Publications with the theme of palliative care involving patient or team communication are still scarce. Only after 2004 (Figure 2) was there an insertion of communication in the scientific discussion in palliative care. The present research contemplates the period between 2001 and 2016, and of the 15 years surveyed, in 7 of them (approximately 46\%), non-consecutive, no publications were found in the area related to the theme. The years that no publications were found were: 2001, 2002, 2003, 2006, 2007, 2008 and 2010. In the years 2004, 2005, 2009, 2012, 2013 and 2015, only one publication per year was observed for the selection. And in the years 2011 and 2014, two in each year. The maximum number of publications found per year was two. Recently, in 2015, an article that aimed to describe, document and characterize the speech and language therapy work in this area, reported not finding a significant number of papers for this discussion 7 . Such a fact 
shows the recent insertion of the speech and language therapist in palliative care teams as well as the outline of his performance.

The characterization of selected scientific output includes half of the articles as bibliographical reviews $(5,50 \%)$, two $(2,20 \%)$ refer to case reports, another two $(2,20 \%)$ are quantitative exploration studies and one $(1,10 \%)$ is a qualitative exploration study (Figure 3). The fact that half of the selected articles are bibliographic reviews shows the lack of field research on this subject. The description of the work with adequate speech and language therapy intervention in palliative care, especially with regard to communication, is still under development and requires research, specialization courses and training ${ }^{10,11}$.

The descriptors found in the articles analyzed (Figure 4), which had more relation to the theme of the work were: palliative care (25.9\%), communication (22.2\%), speech and language therapy (14.8\%), quality of life $(11.1 \%)$, dysphagia (11.1\%), swallowing (7.4\%) and elderly $(7.4 \%)$, with approximate percentage values. Some of the descriptors found were repeated in different articles; therefore, the total number of descriptors is greater than the number of selected articles. It is important to standardize the descriptors so that the intended information is adequately disclosed. Notably, the descriptor "communication" appears more than "Speech and Language Therapy," and in this way, it is relevant that the two terms are described in speech and language therapy work, reinforcing this relationship, since it is neither logical nor direct in this area yet.

A relevant aspect addressed in 4 of the 10 articles selected is the importance of patient communication in palliative care. The effectiveness of a type of communication improves the link between patient and team, and between patient and family. In addition, it allows the patient to express his decisions and maintain social contact, allowing his requests to be attended until the end of life ${ }^{2,6}$.

Five types of descriptions of the speech and language therapist's role/participation in palliative care (Figure 5) were found, namely: favoring patient-family and patient-team intervention (45\%), managing and intervening in communication and swallowing (35\%), offering family support $(11 \%)$ and evaluating the patient (11\%). It is important to emphasize that $4(40 \%)$ articles did not present any description of the speech and language therapist's role/participation, but those that did so, stated more than one role or participation of the speech and language therapist in palliative care, and therefore, the total number is higher than the number total of selected articles.

The patient undergoing palliative care may present communication difficulties as a consequence of his illness and for this reason, must be evaluated by a speech and language therapist. Despite the evidence of the importance of this work, there are still few professionals trained to work in this area. The work in the communication area of this type of patient includes direct therapy with the patient, training of individuals to facilitate the communication with the family and caregivers and the use of alternative communication mechanisms, such as gestures and non-verbal communication, communication boards, systems and prostheses (voice) $)^{4,12}$.

According to the analysis, in terms of means and/ or communicative aspects, half of the articles (50\%) present suggestions for communication strategies and $50 \%$ do not mention them. The communication strategies cited in the articles found and selected were: non-verbal communication (33.4\%), communication board $(22.2 \%)$, electronic equipment $(22.2 \%)$, verbal communication (11.1\%) and speech valve (11.1\%) (Figure 6).

A study involving a palliative care team investigated whether the professionals knew strategies or techniques of interpersonal communication, identifying which were the communicative strategies that facilitated the interaction. The most mentioned verbal strategies were those of an interrogative nature about the disease/ treatment and, among the non-verbal ones, those that stood out were affective touch, look, smile, physical proximity and active listening. Although professionals assigned a high degree of relevance to communication in palliative care, they showed little knowledge of communication strategies and use of verbal communication of an interrogative nature ${ }^{13}$. The interrogative nature refers to questions asked to the patient, considering the cases in which the patient is unable to use oral communication; therefore, in the absence of a method in which he can communicate non-verbally, the patient's suffering and anguish increase faced with questions they are asked.

Non-verbal communication was the most cited in the studies analyzed and can range from the use of indicative and representative gestures, associated with head and facial expression, to complementary and alternative communication, with or without technological resources. Although there are efficient, standardized 
and available means for effective non-verbal communication, there is a lack of knowledge of professionals and the population about this resource, which can be described as Alternative and Supplementary Communication.

Alternative and Supplementary Communication concerns a series of symbols and sets of systems that allow the communication of persons who are unable to use oral language. These systems may be implemented through the use of computers, tablets and/or sound synthesizer and sound tray "machines," but they can also be done using paper boards ${ }^{14}$.

In Brazil, there are different nomenclatures to refer to Alternative and Supplementary Communication. In a 2009 study, the following nomenclatures used in Brazil were found: Alternative and Supplementary Communication, Alternative Communication, Supplementary and/or Alternative Communication, Alternative Communication Systems and Facilitators, Supplementary Communication, Alternative and Expanded Communication. This same study highlights the importance of a single nomenclature version for the consecration and strengthening of CSA in Brazil as well as for the definition of descriptors in Health ${ }^{14}$.

The decision to use these resources involves criteria already mentioned previously, and which are completely related to the patients and the possibilities of the use of these resources by the individuals who are related to them. The first proposal to be sought would be to expand and disseminate the knowledge of Alternative and Supplementary Communication among speech and language therapists, other health professionals and Palliative Care teams that already work in hospitals, and to extend this knowledge to the hospitals and clinics for the rehabilitation of seriously ill patients which, therefore, fit within Palliative Care. Way beyond knowledge, it is important to implement this service mainly in the palliative care team, and which even without great technological resources and the high cost, can use standardized strategies that can meet the more urgent communication needs of these patients with the family and the medical team.

The early insertion of the speech and language therapist into the palliative care team will allow the maintenance of oral communication while possible and will work the transition to alternative communication, protecting the right of expression without interrupting the possibility of communication ${ }^{2}$. While oral communication is possible, the speech valve may be necessary for tracheostomized or mechanically ventilated patients, allowing the diversion of the expiratory air to the larynx, vibrating the vocal folds and delivering sound to the speech, respecting the indication criteria and taking care of contraindications, which include a severe clinical condition ${ }^{8}$.

\section{CONCLUSION}

The analysis of the characterization of communication in palliative care in the last 15 years allows us to conclude that the attention to communication is recent, with few reports yet described, it includes non-verbal communication in different ways as the most frequent resource, but it provides oral communication as an important factor for maintaining dignity and comfort in this scenario. The speech and language therapist is the main interlocutor for the maintenance, mediation and adaptation of communication, both among a multiprofessional team, and among the patient, his family and the care team.

\section{REFERENCES}

1. World Health Organization (WHO). National cancer control programmes: policies and managerial guidelines. $2^{\text {nd }}$ ed. Geneva; WHO, 2002.

2. Pollens R. Role of the speech-language pathologist in palliative hospice care. J Palliat Med. 2004;7(5):694-702

3. Aguirre-Bravo NA, Sampallo-Pedroza R. Fonoaudiologia em los cuidados paliativos. Rev. Fac. Med. 2015;63(20):289-300.

4. Calheiros AS, Albuquerque CL. A vivência da fonoaudiologia na equipe de cuidados paliativos de um Hospital Universitário do Rio de Janeiro. Revista Hupe. [periódico na internet]. 2012 [acesso em julho 2016]; 11(2):94-8. Disponível em: www.revista.hupe.uerj.br.

5. O'Reily AC, Walshe M. Perspectives on the role of the speech and language therapist in palliative care: An international survey. Palliative Med. 2015;29(8):756-61

6. Araujo MMT, Silva MJP. Estratégias de comunicação utilizadas por profissionais de saúde na atenção à pacientes sob cuidados paliativos. Rev da Esc Enferm USP. 2012;46(3):626-32.

7. Chun RYS. Augmentative and alternative communication: scope and peculiarities of terms and concepts in Brazil. Pró-fono R Atual Cient. 2009;21(1):69-74. 
8. Silveira MH, Ciampone MHT, Ozello BA. Percepção da equipe multiprofissional sobre os cuidados paliativos [periódico na internet]. Rev Bras de Geriat e Geront; 2014. Data [acesso em julho 2016]; 17(1):7-16. Disponível em www.rbgg.com.br.

9. Perez AIG, Dapueto JJ. Case reporto f a Computer -Assisted Psycotherapy of a patient with ALS. Int J Psychiat Med. 2014;48(3):229-33.

10. Academia Nacional de Cuidados Paliativos (ANCP). Manual de Cuidados paliativos. 2.a edição, ANCP 2012.

11. Radtke JV, Baumann BM, Garret KL, Happ MB. Listening to the voiceless patient: case reports in assisted communication in the intensive care unit. J Palliative Med. 2011;14(6):791-5.

12. Tavares MS, Silva MD, Carvalho R. Revisão integrativa: o que é e como fazer? Einstein. 2010;8(1):102-6.

13. Andrade CG, Costa SFG, Lopes MEL. Cuidados paliativos: a comunicação como estratégia de cuidado para o paciente em fase terminal. Ciência e Saúde Coletiva [periódico na internet]. 2013 [acesso em: julho 2016]; 18(9):2523-30. Disponível em: www.cienciaesaudecoletiva.com.br.

14. Eckman S, Roe J. Speech and language therapists in palliative care: what do we have to offer. Int $\mathrm{J}$ Palliative Care. 2005;11(4):179-81. 


\section{ADDENDUM 1}

\begin{tabular}{|c|c|c|c|c|c|}
\hline Ano / Autor & Título & Descritores & $\begin{array}{l}\text { Tipo de } \\
\text { estudo }\end{array}$ & $\begin{array}{c}\text { Papel e/ou participação do } \\
\text { fonoaudiólogo nos cuidados } \\
\text { paliativos }\end{array}$ & $\begin{array}{l}\text { Meios e/ou aspectos } \\
\text { comunicativos }\end{array}$ \\
\hline $\begin{array}{c}2015 \\
\text { Aguirre-Bravo AN; } \\
\text { Sampallo-Pedroza, R. }\end{array}$ & $\begin{array}{l}\text { Fonoaudiología em los } \\
\text { cuidados paliativos }\end{array}$ & $\begin{array}{l}\text { Cuidados paliativos; } \\
\text { disfagia; dor; } \\
\text { qualidade de vida; } \\
\text { Fonoaudiologia }\end{array}$ & $\begin{array}{c}\text { Revisão } \\
\text { bibliográfica }\end{array}$ & $\begin{array}{c}\text { - Considerar os cuidados } \\
\text { paliativos não apenas em casos } \\
\text { terminais. } \\
\text { - Reconsiderar objetivos } \\
\text { terapêuticos, levando em conta a } \\
\text { situação do paciente. } \\
\text { - Assegurar a comunicação e a } \\
\text { eficácia da deglutição. } \\
\text { - Maximizar a comunicação não } \\
\text { verbal. } \\
\text { - Realizar massagens quando há } \\
\text { queixa de dor. } \\
\text {-Adequar volume do alimento, } \\
\text { mas não esquecer de selecionar } \\
\text { um sabor de preferência do } \\
\text { paciente a fim de minimizar o } \\
\text { sofrimento. }\end{array}$ & $\begin{array}{l}\text { Maximizar comunicação não } \\
\text { verbal. }\end{array}$ \\
\hline $\begin{array}{l}2014 \\
\text { Silveira MH, Ciampone } \\
\text { MHT, Ozello BA. }\end{array}$ & $\begin{array}{l}\text { Percepção da equipe } \\
\text { multiprofissional sobre } \\
\text { cuidados paliativos. }\end{array}$ & $\begin{array}{l}\text { Idosos; } \\
\text { Cuidados paliativos; } \\
\text { Equipe de assistência } \\
\text { ao paciente; } \\
\text { Saúde do trabalhador. }\end{array}$ & $\begin{array}{l}\text { Explorativa } \\
\text { qualitativa }\end{array}$ & $\begin{array}{l}0 \text { fonoaudiólogo participa } \\
\text { da pesquisa como um dos } \\
\text { profissionais da equipe } \\
\text { multidisciplinar, mas não é } \\
\text { descrito o trabalho que realiza e o } \\
\text { seu papel. }\end{array}$ & $\begin{array}{l}\text { Não descreve nenhuma } \\
\text { estratégia de comunicação }\end{array}$ \\
\hline $\begin{array}{l}2014 \\
\text { Perez, AIG, Dapueto JJ }\end{array}$ & $\begin{array}{l}\text { Case Report of a } \\
\text { Computer- Assisted } \\
\text { Psychoterapy of a } \\
\text { Patient with ALS }\end{array}$ & $\begin{array}{l}\text { Idoso; Esclerose } \\
\text { Lateral Amiotrófica; } \\
\text { Comunicação; } \\
\text { Cuidados paliativos; } \\
\text { Terapia cognitiva; } \\
\text { Estratégias de } \\
\text { Comunicação. }\end{array}$ & $\begin{array}{l}\text { Relato de } \\
\text { caso }\end{array}$ & $\begin{array}{c}\text { Não descreve o papel específico } \\
\text { do fonoaudiólogo no caso } \\
\text { descrito }\end{array}$ & $\begin{array}{l}\text { Paciente usa inicialmente } \\
\text { para se comunicar com o } \\
\text { Psicoterapeuta uma prancha } \\
\text { de comunicação com letras } \\
\text { do alfabeto, posteriormente } \\
\text { foi utilizado um programa de } \\
\text { computador, com displays de } \\
\text { figuras, voz natural e preditores } \\
\text { de palavras. }\end{array}$ \\
\hline $\begin{array}{l}2013 \\
\text { Andrade CG, Costa } \\
\text { SFG, Lopes MEL }\end{array}$ & $\begin{array}{l}\text { Cuidados paliativos: } \\
\text { a comunicação como } \\
\text { estratégia de cuidado } \\
\text { para o paciente em fase } \\
\text { terminal. }\end{array}$ & $\begin{array}{l}\text { Comunicação; } \\
\text { Cuidados paliativos; } \\
\text { Enfermagem. }\end{array}$ & $\begin{array}{c}\text { Exploratória } \\
\text { qualitativa }\end{array}$ & $\begin{array}{c}\text { Não descreve o papel específico } \\
\text { do fonoaudiólogo }\end{array}$ & $\begin{array}{c}\text { Comunicação verbal e não } \\
\text { verbal. }\end{array}$ \\
\hline $\begin{array}{c}2012 \\
\text { Calheiros AS, } \\
\text { Albuquerque CL }\end{array}$ & $\begin{array}{c}\text { A vivência da } \\
\text { fonoaudiologia na } \\
\text { equipe de cuidados } \\
\text { paliativos de um } \\
\text { Hospital Universitário do } \\
\text { Rio de Janeiro. }\end{array}$ & $\begin{array}{l}\text { Cuidados paliativos; } \\
\text { Fonoaudiologia; } \\
\text { deglutição; } \\
\text { comunicação. }\end{array}$ & $\begin{array}{l}\text { Revisão } \\
\text { bibliográfica }\end{array}$ & $\begin{array}{l}\text { Descreve a importância do } \\
\text { trabalho da Fonoaudiologia na } \\
\text { equipe de cuidados paliativos, } \\
\text { aumentando a interação do } \\
\text { paciente com a família através } \\
\text { do trabalho na comunicação do } \\
\text { paciente e preservando de forma } \\
\text { segura o prazer da alimentação } \\
\text { por via oral }\end{array}$ & $\begin{array}{l}\text { Não descreve estratégias de } \\
\text { comunicação. }\end{array}$ \\
\hline $\begin{array}{c}2011 \\
\text { Radtke JV, } \\
\text { Baumann BM, } \\
\text { Garret KL, Happ MB }\end{array}$ & $\begin{array}{l}\text { Listening to the } \\
\text { Voiceless Patient: Case } \\
\text { Reports in Assisted } \\
\text { Communication in the } \\
\text { Intensive Care Unit }\end{array}$ & $\begin{array}{l}\text { Estratégias de } \\
\text { comunicação; } \\
\text { Unidades de Terapia } \\
\text { Intensiva; Relação } \\
\text { médico paciente; } \\
\text { Fonoaudiologia }\end{array}$ & $\begin{array}{l}\text { Relato de } \\
3 \text { casos }\end{array}$ & $\begin{array}{l}\text { Apresenta as estratégias de } \\
\text { comunicação usado pelo } \\
\text { fonoaudiólogo, em três casos } \\
\text { diferentes, possibilitando ao } \\
\text { paciente a participação das } \\
\text { discussões de seu tratamento,a } \\
\text { tomada decisões e a falar suas } \\
\text { ultimas mensagens. }\end{array}$ & $\begin{array}{l}\text { As estratégias vão de tabuas, } \\
\text { desenhos, mais simples e } \\
\text { baratos, até equipamentos } \\
\text { eletrônicos mais caros. } \\
\text { - pranchas com as letras do } \\
\text { alfabeto } \\
\text { - válvula de fala } \\
\text { - articulação sem som } \\
\text {-Dynavoxtecnologie } \\
\text { - equipamento eletrônico, onde } \\
\text { digitava as letras e saía o voz } \\
\text { pelo equipamento. }\end{array}$ \\
\hline
\end{tabular}




\begin{tabular}{|c|c|c|c|c|c|}
\hline Ano / Autor & Título & Descritores & $\begin{array}{l}\text { Tipo de } \\
\text { estudo }\end{array}$ & $\begin{array}{c}\text { Papel e/ou participação do } \\
\text { fonoaudiólogo nos cuidados } \\
\text { paliativos }\end{array}$ & $\begin{array}{l}\text { Meios e/ou aspectos } \\
\text { comunicativos }\end{array}$ \\
\hline $\begin{array}{l}2011 \\
\text { Araujo, MMT, } \\
\text { Silva MJP }\end{array}$ & $\begin{array}{c}\text { Estratégias de } \\
\text { comunicação utilizadas } \\
\text { por profissionais de } \\
\text { saúde na atenção à } \\
\text { pacientes sob cuidados } \\
\text { paliativos. }\end{array}$ & $\begin{array}{c}\text { Comunicação; } \\
\text { Cuidados paliativos; } \\
\text { Equipe de assistência } \\
\text { ao paciente; Relações } \\
\text { interpessoais }\end{array}$ & $\begin{array}{l}\text { Exploratório } \\
\text { quantitativo }\end{array}$ & Muldisciplinar & $\begin{array}{c}15,2 \% \text { mencionaram } \\
\text { estratégias não verbais. } \\
\text { Os profissionais de saúde } \\
\text { mostraram apresentar escasso } \\
\text { conhecimento em estratégias } \\
\text { de comunicação. } \\
57,7 \% \text { deles não foram } \\
\text { capaz de citar ao menos uma } \\
\text { estratégia de comunicação } \\
\text { verbal }\end{array}$ \\
\hline $\begin{array}{c}2009 \\
\text { Chun RYS }\end{array}$ & $\begin{array}{c}\text { Comunicação } \\
\text { suplementar e/ou } \\
\text { alternativa: abrangência } \\
\text { e peculiaridades dos } \\
\text { termos e conceitos em } \\
\text { uso no Brasil }\end{array}$ & $\begin{array}{c}\text { Patologia da Fala } \\
\text { e da Linguagem; } \\
\text { Terminologia; } \\
\text { Comunicação Não } \\
\text { Verbal }\end{array}$ & $\begin{array}{l}\text { Revisão de } \\
\text { literatura }\end{array}$ & $\begin{array}{l}\text { Cita livros escrito por } \\
\text { fonoaudiólogos onde é possível } \\
\text { encontrar os diferentes termos } \\
\text { para Comunicação Alternativa, } \\
\text { mas não define explicitamente a } \\
\text { função do fonoaudiólogo no uso } \\
\text { desse recurso. }\end{array}$ & $\begin{array}{l}\text { Não descreve as estratégias } \\
\text { em Comunicação Alternativa }\end{array}$ \\
\hline $\begin{array}{c}2005 \\
\text { Eckman S, Roe J }\end{array}$ & $\begin{array}{c}\text { Speech and language } \\
\text { therapists in palliative } \\
\text { care: what do we have } \\
\text { to offer }\end{array}$ & $\begin{array}{c}\text { Disfagia; Cuidados } \\
\text { Paliativos; Desordens } \\
\text { de fala;Terapia de fala }\end{array}$ & $\begin{array}{l}\text { Revisão } \\
\text { Bibliográfica }\end{array}$ & $\begin{array}{c}\text { Descreve que a literatura } \\
\text { reconhece que os pacientes em } \\
\text { Cuidados Paliativos deverão ser } \\
\text { avaliados por um fonoaudiólogo, } \\
\text { no entanto há ainda poucas } \\
\text { evidências na literatura para } \\
\text { dar suporte ao trabalho desses } \\
\text { profissionais com esses } \\
\text { pacientes. } \\
\text { A inclusão do fonoaudiólogo } \\
\text { na equipe multidisciplinar é um } \\
\text { processo lento. Ainda temos } \\
\text { poucos profissionais treinados } \\
\text { para o trabalho em cuidados } \\
\text { paliativos e deve haver portanto, } \\
\text { um aumento nas oportunidades } \\
\text { de educação na área, tanto } \\
\text { na graduação como na pós } \\
\text { graduação, para assegurar que } \\
\text { os fonoaudiólogos estejam } \\
\text { habilitados em trabalhar na área. }\end{array}$ & $\begin{array}{l}\text { Não cita estratégias de } \\
\text { comunicação específicas. }\end{array}$ \\
\hline $\begin{array}{l}2004 \\
\text { Pollens R }\end{array}$ & $\begin{array}{l}\text { Role of the Speech- } \\
\text { Language Pathologist in } \\
\text { Palliative Hospice Care }\end{array}$ & $\begin{array}{c}\text { Cognição; } \\
\text { Comunicação; } \\
\text { Disfagia; Hospice; } \\
\text { Cuidados Paliativos; } \\
\text { Relação profissional- } \\
\text { paciente; Qualidade de } \\
\text { vida; Fonoaudiologia }\end{array}$ & $\begin{array}{l}\text { Revisão } \\
\text { Bibliográfica }\end{array}$ & $\begin{array}{l}\text { Funções dos Fonoaudiólogos em } \\
\text { Cuidados paliativos Paliativos: } \\
\text { - Atendimentos nas áreas de } \\
\text { comunicação, cognição e } \\
\text { deglutição. } \\
\text { - Criar estratégias de } \\
\text { comunicação, para que o } \\
\text { paciente possa expressar suas } \\
\text { decisões e manter o contato } \\
\text { social. } \\
\text { - Tentar manter uma deglutição } \\
\text { funcional, com objetivo de manter } \\
\text { o conforto e o prazer oral do } \\
\text { paciente. } \\
\text { - Manter uma comunicação } \\
\text { efetiva com a equipe } \\
\text { multidisciplinar. } \\
\text { Desta forma o fonoaudiólogo, } \\
\text { fazendo parte da equipe } \\
\text { multidisciplinar, pode ajudar } \\
\text { no objetivo de dar um cuidado } \\
\text { de qualidade, para pacientes e } \\
\text { familiares dessas clínicas. }\end{array}$ & $\begin{array}{c}\text { Não cita estratégias específicas } \\
\text { de comunicação. }\end{array}$ \\
\hline
\end{tabular}

